\begin{tabular}{|c|c|}
\hline Title & Japan, the European Union, and W aste Electronic and Electrical Equipment Recycling: Key Lessons Learned \\
\hline Author(s) & Yoshida, Fumikazu; Y oshida, Haruyo \\
\hline Citation & $\begin{array}{l}\text { Environmental Engineering Science, } 27(1), 21-28 \\
\text { https://doi.org/10.1089/ees.2009.0109 }\end{array}$ \\
\hline Issue Date & 2010-01 \\
\hline Doc URL & http:/hdl.handle.net/2115/50812 \\
\hline Rights & $\begin{array}{l}\text { This is a copy of an article published in the Environmental Engineering Science } \odot 2010 \text { copyright Mary Ann Liebert, } \\
\text { Inc.; Environmental Engineering Science is avail lable online at: http://www.liebertonline.com. }\end{array}$ \\
\hline Type & article \\
\hline File Information & yoshida_ees27-1.pdf \\
\hline
\end{tabular}

Instructions for use 


\title{
Japan, the European Union, and Waste Electronic and Electrical Equipment Recycling: Key Lessons Learned
}

\author{
Fumikazu Yoshida ${ }^{1, *}$ and Haruyo Yoshida ${ }^{2}$ \\ ${ }^{1}$ Graduate School of Public Policy, Hokkaido University, Sapporo Japan. \\ ${ }^{2}$ Faculty of Business Administration, Sapporo University, Sapporo, Japan.
}

Received: March 27, 2009 Accepted in revised form: July 14, 2009

\begin{abstract}
This article considers how Japan and the EU manage the recycling of consumer appliances and PCs/cellular phones through a review of their current collection and treatment systems for WEEE (waste electronic and electrical equipment), and on the basis of its findings offers recommendations for the improvement of these systems. We hope thereby to provide information that will be helpful for the better management of WEEE in developed countries as well as in our own. On the basis of our findings, we make the following recommendations: (1) that if Japan hopes to increase its collection rate of WEEE, it has to change its system from one where payment is made at the time of disposal to one where payment is made in advance, whereas the EU has to offer both users and recyclers greater incentives to collect more WEEE; (2) that, within the Japanese system, we have to reduce the cost without reducing the quality of recycling, which, because consumers pay at the time of disposal, is too expensive, whereas the EU must restore the former quality of its recycling, which has been allowed to deteriorate because of the pressure to reduce costs; and (3) that Japan and the EU need to set up a common fund that will enable them to cooperate in the collection and treatment of WEEE to oversee the problems occasioned by the practice of cross-border recycling.
\end{abstract}

Key words: WEEE; collection; treatmentl; generation; recycling

\section{Introduction}

$\mathbf{T}$ HE ACRONYM WEEE (waste electronic and electrical equipment) signifies a relatively new category of waste type, a category that includes precious metals as well as such toxic substances as lead $(\mathrm{Pb})$ and polybrominated biphenyls (PBBs), and one whose components require separate sorting and special treatment for waste management. When certain components of WEEE are regarded as valuable goods there is a tendency for them to be dispatched to other countries, where, if their treatment is not supervised under proper safety conditions, it may ultimately cause serious air pollution, contamination of the soil and groundwater pollution, as when, for instance, strong acids are used for metal extraction and burn used wire (BAN SVTC 2002; Yoshida and Yoshida, 2008; Zheng et al., 2008). To tackle such problems as these, the OECD (Organization for Economic Cooperation and Development) has proposed that countries should adopt the EPR (Extended Producers Responsibility) principle, and the EU, for one, has implemented the WEEE and RoHs Directives to collect WEEE separately from other municipal solid waste

*Corresponding author: Graduate School of Public Policy, Hokkaido University, Sapporo 060-0809, Japan. Phone:+81-11-706-2782; Fax:+81-11-706-4947; E-mail: yoshida@econ.hokudai.ac.jp
(MSW) andd to manage it with the participation of producers (financially and/or physically). Between 2001 and 2005, countries such as Japan and the member countries of the $\mathrm{EU}$, introduced the EPR principle into their WEEE recycling systems.

The purpose of this article is to draw lessons from the ways in which developed countries, in this case Japan and the EU, are managing to deal with WEEE. Japan launched its own WEEE recycling system in 2001, and 5 years later the Japanese government conducted a review of how the system was working; it released its final report, based on documents submitted by Japan's Home Appliance Recycling System Review Council, in February, 2008. Meanwhile, the EU, which had implemented its WEEE Directive in August 2005, had already reviewed the system and had issued its report in August 2007 (UNU, 2008; Review of Directive 2002/96 on WEEE, Final Report, 2007, under the title "EU Review Report"; UNU, 2007). By analyzing these documents, and by performing a field survey (in Germany, Holland, Sweden, Austria, and France), the present authors were able to conduct a comparative study of Japan and the EU as developed countries with respect to the achievements and challenges of their WEEE recycling systems: we focused on three dimensions: (1) material flow analysis, (2) regime-actor analysis, and (3) economical analysis, which the study of circular economy requires (see Yoshida, 2005). Previous studies of WEEE have 
focused in the main upon aspects of the material flow (Jofre and Morioka, 2005; Tasaki, 2006; Terazono et al., 2006) or on an analysis of the economical features (Hosoda, 2007). Here, we attempt to analyze the WEEE recycling system through a focus on a combination of three interrelated issues: (1) the need to improve the collection rate of WEEE, (2) questions of the cost and the quality of recycling, and (3) the problems of crossborder recycling.

This artricle looks at, in order: (1) the systemic character of WEEE recycling in Japan and the EU, (2) the collection rate, (3) the cost and the quality of the recycling, (4) the problems raised by the export of WEEE, and (5) the reuse agenda.

\section{Japan's Home Appliance Recycling System and the EU's WEEE Directive: Purpose and Background}

Japan's consumer equipment recycling system requires that consumers pay a recycling fee when discarding any one of four equipment types (TVs, air conditioners, refrigerators, and washing machines), that retailers take them back, and that producers recycle them. Two problems underly the successful creation of Japan's home appliance recycling system: the shortage of landfill space and the need for the recovery and use of resources. A characteristic of the system is that Japanese municipalities do not, as is the case in some other countries, themselves perform the collection and processing operations for recycling. The recycling fee and fund is managed by the Association for Electric Home Appliances (AEHA, 2008), while the collection and processing are carried out under a producer partnership system that is divided between Group A (Panasonic/Toshiba Group) and Group B (Mitsubishi/Hitachi Group). Although the government sets the recycling rate for the four items that are to be collected, PCs, on the other hand, are supposed to be collected and recycled under the Law for the Promotion of the Utilization of Recycled Resources. Unfortunately, the collection rate achieved by the manufactures is not even $10 \%$ of the PCs that are presumed to be discarded, whereas many of these PCs are shipped abroad (Fig. 2). In the case of cellular phones, the take-back rate in 2006 was estimated at about no more than 15\% (6.62 million/47 million).

By contrast, a characteristic of the EU's WEEE Directive is the broad spectrum of items that it covers, for, in addition to the four types specified by the Japanese directive, it includes: (1) large household appliances, (2) small household appliances, (3) IT (information technology) equipment, (4) consumer equipment (TVs, etc.), (5) lighting appliances, (6) power tools, (7) toys, leisure, and sports equipment, (8) medical equipment, (9) monitoring and control instruments, and (10), vending machines and ATMs (automatic teller machines). A second characteristic of the EU directive, with respect to the responsibility for collection and allocation of costs, is that, for new products, producers are responsible for their own products, but that all producers shall cover costs jointly when products that are already on the market are discarded by consumers. Until 2011 (2013 for large white goods), however, producers will be permitted to add waste processing costs to the prices of new products separately (visible fee). Third, the Directive set a collection target of $4 \mathrm{~kg}$ per capita to be reached by December 31, 2006. The Directive also established recycling rates (for paying recyclers but not for thermal recycling) and recovery rates (to include thermal recycling). Fourth, the Restriction of Hazardous Substances in Electrical and Electronic Equipment (RoHS) Directive banned the use of lead, mercury, cadmium, hexavalent chrome, PBBs, and polybrominated diphenyl ethers (PBDEs) (brominated flame retardants), to be effective by July 1,2006 . This regulation is based on Article 95 of the Amsterdam Treaty (which guarantees the free distribution of goods in the EU common market and restricts the freedom of individual countries to act unilaterally) and implements the same controls throughout the EU common market, whereas the WEEE Directive itself is an independent initiative. Thus, the EU regulations (1) cover a broad range of products, (2) assign responsibility and costs to producers, (3) establish collection targets and recycling rates, and (4) limit the use of hazardous substances. Their purpose is to build a system that, by these means, recovers WEEE separately rather than disposing of it as municipal solid waste (OKOPOL, 2007). The municipality is an important actor or stakeholder in the WEEE recycling system and the recovery of resources is not the main target in the EU.

\section{The Collecting Rate: What Has Japan Achieved So Far?}

Previously, only valuable metals were recovered from discarded household appliances, and the great majority were then land-filled; now, under the new system, introduced in 2001, about half of all discarded appliances are treated after collection.

1. Amounts collected and treated: 11 million units collection/year, 0.45 million ton treatment /year, about $3.5 \mathrm{~kg}$ per capita of the four items;

2. Material recovered: 0.33 million ton/year; this does not include payment to recyclers for accepting waste;

3. Effects on the environment: reduction of landfill (extended for the remaining years from 12.8 year in 2001 to 14.8 year in 2006), recovery and treatment of Chlorofluorocarbons (CFCs) (about 2000 ton in 2006), management of hazardous substances;

4. Design for the environment: long-life design, design for easy disassembly and for the recovery of plastics (Aizawa et al., 2008; Joint Meeting, 2008a).

Reviews of the both the Japanese and European systems have found that increasing the collection rate is a vital requirement. In Japan, 17.2 million of an estimated 22 million units are taken back by retail stores, of which, 11 million units are recycled by their producers, while the rest disappear in an "invisible flow"; and while the primary collection rate at retail stores is $75 \%$, the final processing rate drops to $50 \%$. The main reason is that of the 17.2 million units taken back by retailers, as many as 6.65 million discarded appliances enter channels outside the system; they have not been issued with recycling tickets, and they are not taken to the processing facilities of producers or other parties (see Fig. 1). Furthermore, because Japan's WEEE recycling system is built around recycling, there is no place in its policy for reuse. Because another underlying factor is the high recycling fee that consumers must pay when turning in an appliance, the authorities, fearful that these conditions would lead to illegal dumping, have considered switching to a system for advance fee payment (AFP). According to a recent survey carried out during April and 


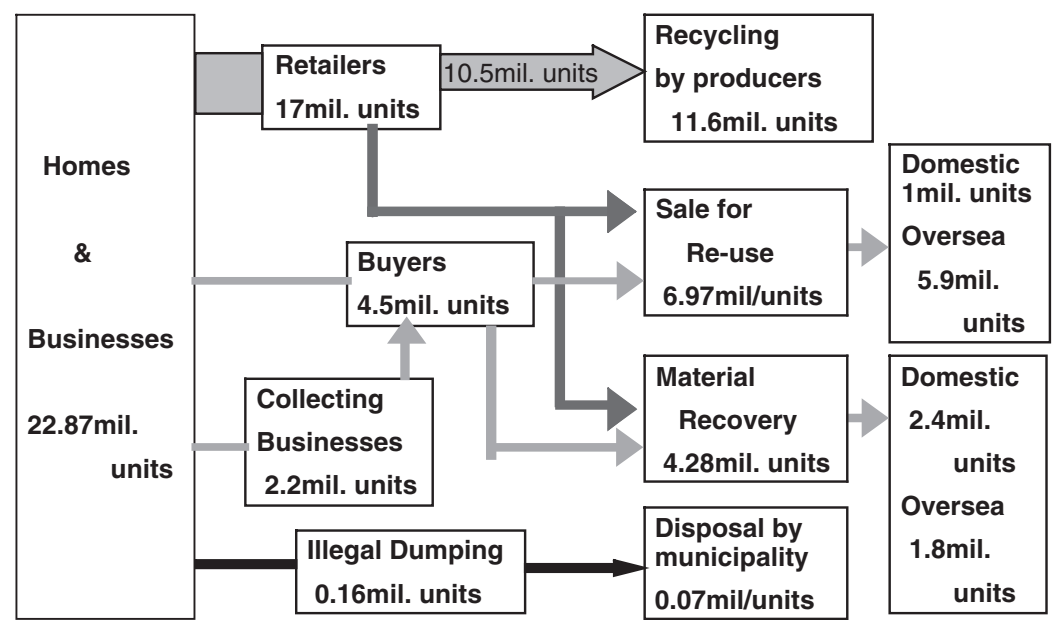

FIG. 1. Japan: main material flow of home appliances (2005).

June 2008 (Joint Meeting, 2008b) of retailers' take-back of the four used items (home appliances), of the 1.9 million units (covering about $1 / 3$ of the four items generated domestically) only $1 \%$ were taken back without payment or with payment by the retailers. Items taken back free of charge go abroad, whereas items that are paid for enter the domestic used market. Although this means that the route from the retailers to points of sale for domestic reuse is decreasing dramatically, only about half (2.2 million) of the number of TVs destined for formal recycling and export (4.1 million) are actually exported (see part of export problems). Consequently, the route taken by the buyers seems to play a major role in determining reuse or material recovery.

The EU's overall collection rate is not so high either, however. Although, in 2005, with a per capita recovery amount of $5.13 \mathrm{~kg}$ (Japan's per capita collection amount for the four types is $3.5 \mathrm{~kg}$ ), the EU had more than attained its 4-kg target, nevertheless, between individual countries, considerable dif- ferences remain: Sweden had collected $12.20 \mathrm{~kg}$ and the UK $9.9 \mathrm{~kg}$, whereas the Czech Republic in Eastern Europe had recovered only $0.33 \mathrm{~kg}$ (Table 1 ). A look at the collection rates for each of the 10 categories shows that, among the 10 product categories, refrigerators and air conditioners account for $27 \%$ of the possible total, with $40 \%$ for large household appliances, $28 \%$ for IT equipment, $30 \%$ for cathode-ray tube (CRT) TVs, and $65 \%$ for monitoring and control instruments (UNU, 2007, Table 56). According to recent WEEE Forum data for 2007, the per capita recovery amount is nearly $7.80 \mathrm{~kg}$ and 11 countries have managed to collect over $4.0 \mathrm{~kg}$. The European Commission (Makela, 2009) has estimated that only 33\% WEEE is reported as collected and treated, that $13 \%$ is landfilled, while $54 \%$ is submitted to substandard treatment both inside and outside the EU.

Because the EU Review Report provides no data country by country, and because differences in categories and definitions necessitate a more detailed analysis, we have had to carry out

Table 1. Collection Performance in the European Union and Japan, 2005

\begin{tabular}{|c|c|c|c|c|c|c|c|c|c|c|c|}
\hline \multirow[b]{2}{*}{ Country } & \multicolumn{10}{|c|}{ Category number } & \multirow{2}{*}{$\frac{\text { Totals }}{1-10}$} \\
\hline & 1 & 2 & 3 & 4 & 5 & 6 & 7 & 8 & 9 & 10 & \\
\hline Japan & 2.58 & n.d. & n.d. & 0.82 & n.d. & n.d. & n.d. & n.d. & n.d. & n.d. & $\mathrm{N} / \mathrm{A}$ \\
\hline Norway & 8.15 & 0.46 & 2.68 & 2.01 & - & - & 0.04 & 0.06 & - & 0.01 & 13.41 \\
\hline Switzerland & 4.19 & 1.40 & 3.52 & 2.17 & 0.12 & 0.04 & 0.01 & 0.00 & 0.00 & 0.00 & 11.44 \\
\hline Austria & 2.00 & 0.3 & 0.1 & 0.2 & 0.1 & Inc 2 & Inc 2 & Inc 2 & Inc 2 & Inc 2 & 2.77 \\
\hline Belgium & 2.99 & 1.12 & 1.16 & 1.64 & 0.20 & 0.14 & 0.00 & 0.02 & 0.00 & 0.00 & 7.26 \\
\hline Czech R & 0.14 & 0.00 & 0.12 & 0.05 & 0.00 & 0.00 & 0.00 & 0.01 & 0.00 & 0.01 & 0.33 \\
\hline Estonia & 0.48 & 0.00 & 0.04 & 0.10 & n.d. & n.d. & n.d. & n.d. & n.d. & n.d. & 0.63 \\
\hline Finland & 4.75 & 0.28 & 1.44 & 1.30 & 0.27 & 0.03 & 0.00 & 0.02 & 0.01 & 0.00 & 8.10 \\
\hline Hungary & 0.91 & 0.04 & 0.09 & 0.22 & 0.01 & 0.00 & 0.00 & 0.00 & 0.00 & 0.00 & 1.27 \\
\hline Ireland & 6.68 & 0.28 & 0.43 & 0.67 & 0.09 & 0.07 & n.d. & n.d. & 0.00 & n.d. & 8.22 \\
\hline Netherlands & 2.59 & 0.53 & n.d. & 1.18 & 0.03 & 0.06 & 0.03 & 0.00 & 0.00 & 0.02 & 4.44 \\
\hline Slovakia & 0.35 & 0.04 & 0.05 & 0.20 & 0.02 & 0.00 & 0.00 & 0.00 & 0.00 & 0.00 & 0.66 \\
\hline Sweden & 5.01 & 1.41 & 2.54 & 2.36 & 0.74 & 0.11 & 0.02 & 0.02 & n.d. & n.d. & 12.20 \\
\hline UK & 7.17 & 0.54 & 0.59 & 1.10 & 0.04 & 0.35 & 0.16 & 0.00 & 0.00 & 0.00 & 9.95 \\
\hline $\mathrm{I} / \mathrm{NO} / \mathrm{CH}$ average & 4.97 & 0.93 & 3.10 & 1.67 & 0.06 & 0.02 & 0.02 & 0.03 & 0.00 & 0.01 & 10.80 \\
\hline Euro average & 3.11 & 0.42 & 0.65 & 0.88 & 0.14 & 0.08 & 0.02 & 0.01 & 0.00 & 0.00 & 5.31 \\
\hline
\end{tabular}

Source: UNU 2007, Table 43: Collection performance (Kg/inhabitant) by Category.

n.d., no data; Inc 2, included in category 2 figure. 
our own research. With respect to the raising of the collection rate, the EU, as we have said, enumerates a broader range of equipment types subject to collection than does Japan, whereas there are also differences in business practices in the take-back of old products when new ones are bought. In Europe, municipalities are an important collection channel, and our interviews in Germany and The Netherlands indicate that because municipalities have a certain amount of discretion over how to dispose of WEEE, equipment is sold as used equipment instead of going from municipal collection centers to processing plants contracted by manufacturers. In the case of items such as air conditioners, which are made largely of metal, a considerable quantity apparently goes to scrap dealers. For that reason, there is a tendency for what is left of the discarded equipment collected by producers to be of lower quality. Consequently, the more that producers recover, then the greater their eventual burden becomes, which means that their incentive for collection remains weak (Husmann et al., 2008).

The cooperative relationships between the actors also differ quite markedly from country to country. French law requires that producers pay the cost of separate collection by municipalities, and there is an officially authorized coordination agency that liaises between municipalities and producers (ADEME, 2007). In The Netherlands, producers used to pay the management expenses of the municipal collection centers, but because this is covered by taxes, they recently stopped doing so, and their decision is now the subject of a lawsuit. Producers desire to create their own collection channels, which would mainly make use of retailers and thus cease to be dependent upon municipalities. Some countries, such as Sweden, have, with the cooperation of municipalities and producers, set up nonprofit collection management systems. There is consequently great variety among the EU countries. Japan can probably learn from this when considering the role of municipalities in increasing the types of equipment to be recycled.

The EU Review Report recommends that consumers should be kept well informed about recycling activities and notified of any significant institutional improvements: among other things, they should be told of the steps that are to be taken to improve cooperation with municipalities, and which are the main recovery channels for used equipment. At the same time, the unregistered movement of waste (outside of the EU, and to Eastern European countries and other places inside the area) must be made illegal, whereas the distinction between business and consumer products must be removed, as must the distinction between new waste and older waste, beccause all such distinctions merely complicate the system
(UNU, 2007). The Commission is therefore proposing revisions to change the collection target for 2016: on average, $65 \%$ by weight of the MS market in two successive years (Makela, 2009).

As for the Japanese system, more positive options that would serve to raise the collection rate are: (1) free take-back when a product is discarded, (2) the use by municipalities of the agreed collection channels, and, (3) paying for the collection. By combining (1) and (2), Korea has achieved a higher collection rate than Japan, as well as including a wider range of categories among the collected items.

\section{Cost and Recycling Quality}

Although some have claimed that the high cost of Japan's recycling process can in part be explained by the recycling fees customers must pay when turning in an old piece of equipment, the producers, who are responsible for WEEE processing, seek to rebut this criticism with the counterclaim that the quality of recycling is also high. Nevertheless, the problems caused by the high cost of recycling could lead to recycling outside the formal scheme and thus encourage the export of WEEE abroad. We must therefore continue to ask the question, is Japan's recycling cost truly high, and, if so, why? Let us examine this issue through a comparison with the EU.

Although the direct costs incurred in recycling household appliances are not publicly released, Japan's Recycling System Review Council has issued a report, "On the Transparency of Recycling Fees" (Joint Meeting, 2007; Table 2), and each year AEHA 2008 publishes the recycling amounts collected and the number of units recycled, whereas information on WEEE in the EU comes from estimates by type of product based on cost data collected by the WEEE-Forum and other bodies (UNU, 2007; Table 3). Calculations based on this information show that in 2005 Japan's costs were 20-60\% higher than those in the EU (see Table 4). In the context of Japan's Household Appliance Recycling Law, one therefore cannot overlook the fact that, at the least, nearly 20 billion JPY (20 million USD) in tax money has been invested in this task.

We offer the following reasons to explain why Japan's recycling costs are higher than those of the EU. In the first place, the system's very structure makes it costly. Because consumers are required to pay recycling fees when they turn in an old appliance, management costs, which are processed through a manifest system, are levied to ensure the traceability of each item. Although the collection management cost in the EU is about $40 \%$ of total costs, in Japan, the collection management cost is nearly $50 \%$. One of the EU countries, The

Table 2. Recycling Cost of Televisions, Refrigerators, and Air Conditioners in Japan

\begin{tabular}{lcrr}
\hline & $T V$ & Refrigerator & Air conditioner \\
\hline Group A per unit & $3,128 \mathrm{JPY}$ & $5,885 \mathrm{JPY}$ & $3,535 \mathrm{JPY}$ \\
Group B per unit & $3,239 \mathrm{JPY}$ & $6,382 \mathrm{JPY}$ & $3,878 \mathrm{JPY}$ \\
Reported treatment units (AEHA) & $3,852,000$ & $2,807,000$ & $1,990,000$ \\
Reported treatment weights (AEHA) & 108,000 tonnes & 162,000 tonnes & 86,000 tonnes \\
units per ton & 36 & 17 & 23 \\
\hline
\end{tabular}

Group A and Group B in 2005 JPY per 1 unit.

Source: Joint Meeting, 2007. 
Table 3. Recycling Cost in the European Union, 2005

\begin{tabular}{|c|c|c|c|c|c|c|c|}
\hline & & \multicolumn{3}{|c|}{ Total costs $[E U R / t]$} & \multicolumn{3}{|c|}{ Technical costs $[E U R / t]$} \\
\hline & & MIN & $M A X$ & Average & MIN & $M A X$ & Average \\
\hline $1 \mathrm{a}$ & LHHA & 54.46 & 457.90 & 235.31 & 41.24 & 386.38 & 162.11 \\
\hline $1 b$ & C\&F & 338.46 & 811.49 & 557.70 & 318.97 & 739.97 & 482.15 \\
\hline 2 & SHA & 272.44 & 499.21 & 383.13 & 182.99 & 426.98 & 280.96 \\
\hline $3 a$ & IT ex CRT & 272.08 & 539.23 & 379.69 & 182.62 & 469.58 & 323.15 \\
\hline $3 b$ & IT CRT & 349.26 & 621.48 & 499.29 & 323.07 & 551.82 & 443.95 \\
\hline $4 a$ & CE ex CRT & 254.48 & 549.37 & 422.12 & 165.02 & 469.58 & 335.41 \\
\hline $4 b$ & CE CRT & 428.55 & 621.41 & 528.01 & 366.93 & 551.76 & 452.76 \\
\hline 5 & Light & 561.15 & 840.00 & 662.83 & 505.38 & 787.12 & 601.49 \\
\hline 6 & Tools & 220.83 & 341.49 & 300.79 & 161.82 & 299.22 & 219.90 \\
\hline 7 & Toys & 409.56 & 609.16 & 495.15 & 340.01 & 483.79 & 394.32 \\
\hline 8 & Med. & 238.64 & 529.79 & 409.64 & 149.19 & 437.93 & 346.92 \\
\hline
\end{tabular}

Source: UNU 2007, Table 87: Breakdown total costs and technical costs per product category for long running compliance schemes, expressed in EUR/tonnes.

Netherlands, has done well by charging visible fees to provide the initial investments for setting up the recycling infrastructure, such as facilities for recovery and processing, whereas, in Japan, the two Groups, A and B (see above), which are partnerships entered into by the manufacturers, conduct collection management and processing independently of each other, and the redundant investment prevents economies of scale.

A further reason is that the heavy involvement of Japanese producers in the task of recycling makes capital investment that much higher. Furthermore, just at a time when the EU is mechanizing its operations to lower costs, Japan is still relying on manual disassembly as well as mechanization to raise the recycling rate. Whereas the EU limits manual disassembly mainly to the removal of hazardous items, Japan makes considerable investments in actually expanding manual disassembly processes to raise the plastic recycling rate, and in the development of technologies and facilities for plastic sorting. Yet, when we examined how recovered plastic is used by Japanese producers, we found that its use in new products is restricted, because even if there is no problem with quality, it would be likely to hamper product sales. Consequently, recovered plastic is only used when, for example, it is mixed, in quantities of about $20 \%$, with virgin materials, and only in parts that are not externally obvious, or for those internal parts of refrigerators that do not come into contact with food. In the EU, on the other hand, even plastic that is incinerated is counted toward the recovery rate.
A third issue concerns the matter of recycling quality and cost. Because Japan's regulations guarantee the recycling charge, manufacturers ask for higher recycling rates without needing to indulge in price competition, thus making the actual rate higher than that legally required. The legal and actual rates are, respectively, 60 and $89 \%$ for air conditioners, 55 and $89 \%$ for TVs, 50 and $74 \%$ for refrigerators, and 50 and $84 \%$ for washing machines (2008). Some observers believe that because of the heavy involvement of producers in processing, Japan is demonstrating its strong design for environment (DfE) feedback, and it is true that there has been a certain degree of progress in this area, particularly in terms of ease of dismantlement and the aforementioned recovery and in the use of plastic; but design has a lower priority than the need for energy-saving performance and the avoidance of hazardous substances, and this is a drawback.

In the EU, on the other hand, producers are not directly concerned with the business of recycling itself. Instead, individual producers or members of the joint scheme enter into individual contracts with specialized recycling companies. Although, under this arrangement, the principle of cost competition works reasonably well, the feedback to DfE and the like is rather weak. More meaningful in terms of DfE are such different schemes as the hazardous substance regulations (RoHS) and the energy-using product $(\mathrm{EuP})$ directives. Yet, although the regulations have led to an increase in the amounts of collected waste and processors have benefited from the larger scale, producers have been inclined to hold

Table 4. Total Cost per Tonne of Recycling in 2005 for Japan and the European Union (1 Euro=137 JPY)

\begin{tabular}{|c|c|c|c|}
\hline & $T V(\mathrm{n}=36)$ & Refrigerator $(\mathrm{n}=17)$ & Air conditioner ( $=23$ units) \\
\hline \multicolumn{4}{|l|}{ Japan } \\
\hline Group A & 112,608 JPY (1024 USD) & 100,045 JPY (909 USD) & 81,305 JPY (744 USD) \\
\hline Group B & 116,604 JPY (1059 USD) & 108,494 JPY (1067 USD) & 89,194 JPY (748 USD) \\
\hline & $T V$ & Refrigerator and Air conditioner & \\
\hline EU average & 72,336 JPY (658 USD) & 75,409 JPY (685 USD) & \\
\hline $\operatorname{Max}$ & 85,077 JPY (773 USD) & 111,107 JPY (1010 USD) & \\
\hline
\end{tabular}

Sources: AEHA 2008, UNU 2007. 
Table 5. Export of Used Color Television from JAPAN In 2008

\begin{tabular}{lccr}
\hline Countries & & Values & $\begin{array}{c}\text { Average unit value } \\
\text { JPY (USD) }\end{array}$ \\
\hline Vietnam & Units & $1,000 J P Y(1,000 U S D)$ & $897(8.7)$ \\
Macao & 773,496 & $693,664(6735)$ & $850(8.3)$ \\
Philippine & 564,803 & $480,079(4661)$ & $1,246(12)$ \\
China & 461,603 & $575,323(5586)$ & $679(6.9)$ \\
Cambodia & 195,628 & $132,794(1289)$ & $982(9.5)$ \\
\hline
\end{tabular}

Source: Japan Trade Statistics.

down processing costs because high-quality discarded equipment is hard to find, and some experts observe that the current recycling quality has actually tended to be lower than before the directive was implemented (Svensson et al., 2005). In response to this weakness, SONY, HP, and Elecrolux set up the European Recycling Platform, and certainly, in the case of office machinery, Individual Producers Responsibility can be feasible and can contribute to the DfE achieved by these companies; in the case of many consumer appliances, however, this model is still not capable of working well. Even so, producers are checking and controlling the processors' management procedures more rigorously and are working within the terms of the environmental regulations more than in the past (Khetriwal et al., 2009). In view of all this, we need to reconsider the cost of recycling and its possible benefits, in terms of both the environment and the economy. Now, in response to a report submitted by Japan's Home Appliance Recycling System Review Council, and against the backdrop of recent steep price increases for natural resources, consumer appliance/electronics makers are leaning toward the lowering of recycling fees, down in the case of air conditioners, for example, as much as $17 \%$.

\section{Export Problems}

Both Japan and the EU have serious problems with the dispatch of WEEE to other countries. In Japan, newly issued trade statistics reveals that used CRTTV (HS code: 8528.72-
990) exported in 2008 accounted for $2,244,356$ units, to the value of $2,251,511,000 \mathrm{JPY}(22,443,00 \mathrm{USD})$, at an average price of 1003JPY (10USD) per unit. The chief importing countries are Vietnam 773,496 units, Macao 564,803 units, Philippines 461,603 units, China 195,628 units, Cambodia 106,354 units. As about 5,360,000 units are formally recycled in 2008, we reckon that, compared to the amounts recycled domestically, about $42 \%$ are exported (Table 5).

In the case of used PCs, research carried out in 2008 by JEITA (Japan Electronics and Information Technology Industries Association) estimated that the number of discarded PCs in 2006 had been about 9.08 million units, of which 0.68 million units were recycled by manufacturer recycling facilities, 0.14 million units by municipalities, 2.60 million units by independent waste management companies, while 1.34 million units were sold domestically, 1.24 million units were exported for reuse and 1.85 units were exported for scrap (see Fig. 2). This means that the formal collecting system (manufactures and municipalities) covers only about $10 \%$ of used PCs.

Economic principles dictate that as long as discarded PCs have market value and the domestic used PC market is saturated, and even if reuse is encouraged and a domestic take-back system is created, it will naturally follow that discarded PCs will be exported rather than enter the domestic recycling/reuse channels, whereas, at the same time and because of wide income differences between countries and areas, PCs will be widely subjected to cascade use. In

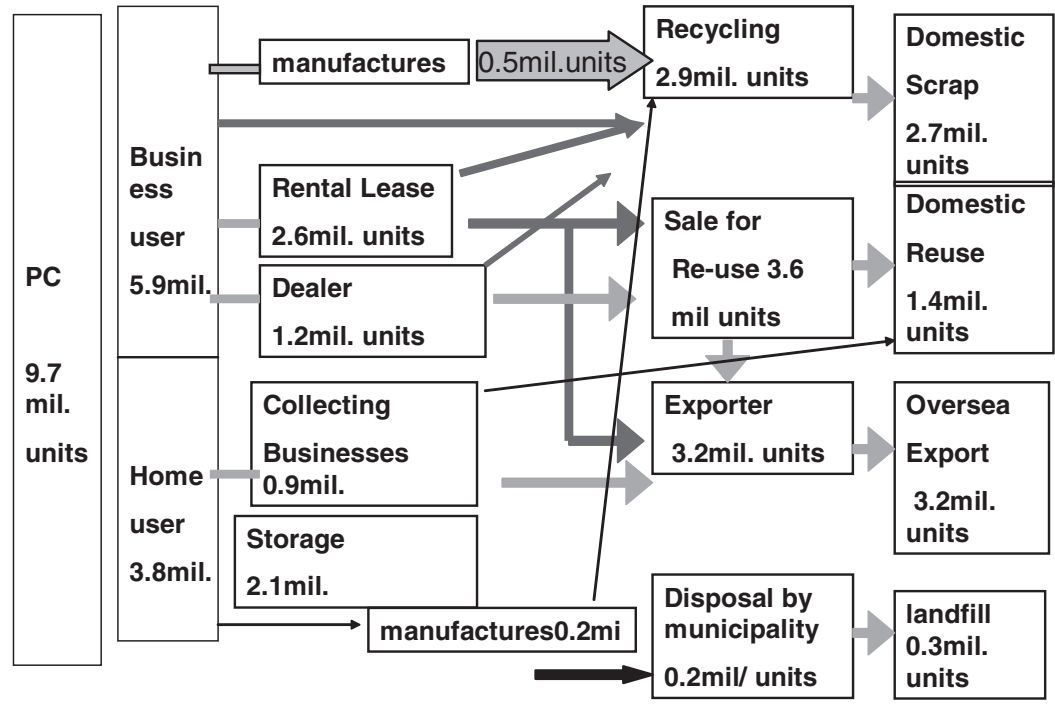

FIG. 2. Japan: main material flow of used PCs (2006). 
Thailand, for example, where used PCs from the country's own domestic market do not satisfy the demand among the middle- and low-income class buyers, the supply of imported PCs are subjected to reuse and are rebuilt. The chief concern, however, centers on what happens to those PCs after the importing countries have, in their turn, discarded them. If Green IT is to be promulgated, then, quite apart from taking care of the WEEE, the business style for the original mass production and mass sales of electrical goods has to be changed.

The EU, however, provides no such estimate of exported WEEE, although it has reported the drain of such waste to other countries from municipality collection centers: in The Netherlands, for example, apparently one-third of scrapped TVs are illegally exported (VROM, 2007), whereas, in the case of France, over $20 \%$ of the scrapped business equipment reported by producers is processed outside of the EU (ADEME, 2007). Furthermore, although the final user of transported business equipment is sometimes required to ensure disposal, the absence of a requirement to report it to the government makes what actually happens quite unclear. In Japan, there is no effective regulation on companies that lease equipment, despite the large amount of WEEE that they generate, and this oversight, so it is supposed, contributes largely to the drain of WEEE overseas. Additionally, Japanese recycling plants sometimes export compressors and other hard-toprocess parts as scrap.

Although the EU has approved the Basel Convention amendments, which virtually ban exports of WEEE, Japan has yet to follow suit. Unfortunately, the reality of international resource cycling practices, which lack any specific controls, entails that the industrialized countries cannot process their hazardous wastes at home, and so, by making the developing countries take the responsibility for dealing with it, they are themselves responsible for damaging human health as well as the environment (Basel Action Network [BAN], 2002). Because the EU Review Report recommends banning illegal shipments of exported waste, it obviously needs to strengthen its export controls on scrapped consumer equipment when these violate the Basel Convention. At the same time, when a developing country such as China, which has environmental problems but also a great demand for resources and a need for imported goods, has installed building facilities for imported scrap disassembly and appropriate processing under the supervision of customs and environmental protection agencies, it becomes necessary to consider the creation of institutions under whose umbrella producers are able to engage in active cooperation and involvement in construction and operation. Although the technologies developed under the recycling systems of Japan and the EU need to be transferred to developing countries, the high-cost constitution of Japan's recycling technologies will remain a stumbling block, and the appropriate domestic treatment of WEEE will be the duty of the developed countries (Yoshida and Yoshida, 2008).

\section{Reuse}

The EU faces similar challenges in facilitating appropriate reuse of WEEE, for although the EU Directive emphasizes the need for the reuse of WEEE, each country in the EU approaches the issue in its own way. Whereas The Netherlands, for example, incorporates reuse into its recycling system by allowing sales to pass through the recovery channels to the used equipment market, France gives precedence to legislation to specify the terms of reuse. In addition, with the cooperation of retailers, producers, and other parties, France has favored the expansion of the numbers of used product retailers to encourage reuse, with the aim of reconciling respect for the environment with the needs of employment, whereas, at the same time, it has sought to provide consumers with lowpriced, high-quality used products (ADEME, 2007). In this respect, the Recycling and Reuse European Union Social Enterprises (RREUSE) are attempting to integrate their economic, social, and environmental aims. They are developing the market for the reuse of WEEE, at the same time as employing and training unemployed workers (Brohl-Kerner, 2008).

Yet although the European Commission has proposed a revision of the Directive to increase targets for the reuse of whole appliances by $5 \%$, the Japanese recycling system assumes that recovered scrapped products will be recycled, because there is hardly any direct reuse of the products or their parts. Currently, the Japanese government is seeking to establish appropriate standards to apply to those used products sent to the used appliance market by retailers without collecting recycling fees, but the guidelines still allow informal curbside collection and the dispatch of WEEE abroad.

Until the current economic crisis overtook us, there had been no slowdown in the speed of social obsolescence for consumer electrical and electronic equipment or for information and communications equipment, while their use had been growing more widespread and at an ever faster rate. Not only do we need to create appropriate reuse systems that also cover the problem of used product exports, but also to design procedures to extend the lifetime of EEE.

\section{Conclusion}

Our analysis of the distinctive WEEE recycling systems operated by Japan and the EU has shown that, in the light of the systems' purposes and contexts, we need to reconsider cost and performance as well as the role of each of the individual actors. We consider that neither system is obviously better than the other, and that they face similar challenges to the achievement of their ultimate goals. Those challenges include the raising of collection rates, the allocation of costs, the involvement of municipalities, recycling cost/benefits, the relationship between EPR and DfE, and the drain of WEEE exports to developing countries. In particular, the key to the raising of the collection rate lies in providing an incentive for proper collection and in making it convenient for the consumer to abide by the adopted scheme. If municipalities are involved, the collection cost has to be paid. Our findings have also revealed that the retailer's role is particularly important. The payment of a recycling fee at the time of discarding curves the collection rate, which must be the real target. The visible fee, or the advance fee payment, does not curve the purchasing power and can contribute to the construction of the infrastructure. In the case of many home appliances, Individual Producers Responsibility cannot work well, and the appropriate domestic treatment of WEEE will be the duty of the developed countries.

Our findings lead us to make the following recommendations: (1) if Japan hopes to increase its collection rate of WEEE to any substantial degree, it has to change its system from one 
where payment is made at the time of disposal to one where payment is made in advance, whereas the EU has to offer both users and recyclers greater incentives to collect more WEEE; (2) that because the consumers have to pay at the time of disposal, the cost and the quality of recycling within the Japanese system is too expensive and must be reduced, whereas under the EU system, on the other hand, the pressures of keeping the costs down has led to worries about the quality of recycling and this has to be attended to; and, (3) that to oversee and amend the problems occasioned by the crossborder problems of WEEE, Japan and the EU need a common agenda and the framework to set up a fund that will enable them to cooperate in the collection and treatment of crossborder recycling.

In the context of the quite unprecedented changes that are now afflicting the global economy, these questions take on a new and disturbing urgency. Instead of simply organizing a WEEE recycling system meant to clean up after the consequences of mass production, mass consumption, and mass disposal, we now need a far more painstaking and balanced assessment of the issues that will cover all their environmental, economic, and social aspects, especially as they relate to each other, for if we hope to see worldwide sustainable development, it is essential that governments design systems that are meant to mitigate environmental and social burdens and reduce the consumption of natural resources by a far more effective management of WEEE.

\section{Author Disclosure Statement}

The authors declare that no conflicting financial interests exist.

\section{References}

Aizawa, H., Yoshida, H., and Sakai, S. (2008). Current results and future perspectives for Japanese recycling of home electrical appliances. Resource Conserv. Recycl. 52, 1399.

ADEME (l'Agence de l'emvironnement et de la maitrise de l'Energie). (2007). Dechets dequipments electriques et electroniques (DEEE). France: ADEME.

AEHA (Association for Electric Home Appliances). (2008). Annual Report. Japan: AEHA.

Basel Action Network (BAN) and Silicon Valley Toxics Coalition (SVTC). (2002). Exporting Harm: The High-Tech Trashing of Asia. Seattle: BAN, and San Jose: SVTC.

Brohl-Kerner, H. (2008). Fair Reuse-Promoting Global Reuse Networks, Proceedings of First World Reuse Forum, Electronics Goes Green 2008, p.13. Berlin.

Hosoda, E. (2007). International aspects of recycling of electrical and electronic equipment: Material circulation in the East Asian region. J. Mater. Cycles Manage. 9, 140.

Husmann, J., Magalini, F., Kuehr, R., and Maurer, C. (2008). Lessons from the 2008 WEEE review research studies. Proceeding of Electronics Goes Green, Berlin, p. 33.

JEITA (Japan Electronics and Information Technology Industries Association). (2008). Research Report on Recovery, Treatment and Recycling of IT Equipments. Japan: JEITA.
Jofre, S., and Morioka, T. (2005). Waste management of electric and electronic equipment: Comparative analysis of end-of-life strategies. J. Mater. Cycles Waste Manag. 7, 24.

Joint Meeting of the Industrial Structure Council, Subcommittee on Waste and Recycling, Electrical and Electronic Equipment Working Group, and Central Environment Council, Waste and Recycling Committee, Subcommittee for Assessing the Household Appliance Recycling System. (2007). On the Transparency of Recycling Fees. 7th joint meeting, March 6, 2007.

Joint Meeting of the Industrial Structure Council, Subcommittee on Waste and Recycling, Electrical and Electronic Equipment Working Group, and Central Environment Council, Waste and Recycling Committee, Subcommittee for Assessing the Household Appliance Recycling System. (2008a). Report on the Assessment and Examination of the Implementation Status of the Household Appliance Recycling System (in Japanese). Joint Meeting.

Joint Meeting of the Industrial Structure Council, Subcommittee on Waste and Recycling, Electrical and Electronic Equipment Working Group, and Central Environment Council, Waste and Recycling Committee, Subcommittee for Assessing the Household Appliance Recycling System. (2008b). The Survey of the Take-Back for the Used 4 Items (Home Appliances) by Retailers during April to June 2008. Joint Meeting.

Khetriwal, D.S., Kraeuchi, P., and Windmer, R. (2009). Producer responsibility for e-waste management: Key issues for consideration-Learning from Swiss experience. J. Environ. Manage. 90, 153.

Makela, T. (2009). The WEEE directive-business generation. Proceedings of IERC2009, Salzburg.

OKOPOL (Okopol GmbH Institute for Environmental Strategies), IIIEE (The International Insitute for Industrial Environmental Economics, Lund University), and RPA (Risk \& Policy Analysts). (2007). The Producer Responsibility Principle of the WEEE Directive, Final Report. Hamburg: OKOPOL.

Svesson, R., Engkvist, 1., Eklund, J., Bjorkman, M., and Eklund, M. (2005). Identified risks at Swedish recycling centres during handling of waste from electric and electronic equipment. Proceedings of Environmentally Conscious Design and Inverse Manufacturing 2005, p. 951.

Tasaki, T. (2006). An Assessment of the Actual Effectiveness of the Household Appliance Recycling Law. Tskubau National Institute for Environmental Studies.

Terazono, A., Moriguchi, Y., Yoshida, A., and Kojima, M. (2006). Current status and research on E-waste issues in Asia. J. Mater. Cycles Manage. 8, 1 .

UNU (United Nations University). (2007). Review of Directive 2002/96 on WEEE, Final Report. Bonn: UNU.

VROM (Ministerie van Volkshuisvesting, Ruimtelijke Ordening en Milieubeheer), Inspectorate. (2007). The Cleaner Picture, Enforcement Action in 2006 on Exports of Waste Electrical and Electronic Equipment. The Netherlands: VROM.

Yoshida, F. (2005). Cyclical Economy of Japan. Japan: Hokkaido University Press.

Yoshida, F., and Yoshida, H. (2008). The circular economy of china: focusing on metal recycling and WEEE recycling (in Japanese). Rev. Environ. Econ. Policy Stud. 1, 14.

Zheng, L., Wu, K., Li, Y., Qi, Z., Han, B., Zhang, C., and Gu, G. (2008). Blood lead and cadmium levels and relevant factors among children from e-waste recycling town in China. Environ. Res. 108, 15. 